\section{RMD Open}

Rheumatic \&

Musculoskeletal Diseases

\title{
Massive nodulous lesions on hands and feet in a RA patient and improvement under baricitinib treatment
}

\author{
Larissa Valor-Méndez (D), Melanie Hagen, Arnd Kleyer, Bernhard Manger (D), \\ Georg Schett
}

To cite: Valor-Méndez L, Hagen M, Kleyer A, et al. Massive nodulous lesions on hands and feet in a RA patient and improvement under baricitinib treatment. RMD Open 2020;6: e001493. doi:10.1136/ rmdopen-2020-001493

Received 23 October 2020 Accepted 2 November 2020

\section{Check for updates}

(c) Author(s) (or their employer(s)) 2020. Re-use permitted under CC BY-NC. No commercial re-use. See rights and permissions. Published by BMJ.

Department of Internal Medicine 3, Rheumatology and Immunology, FriedrichAlexander-Universitat ErlangenNurnberg,Erlangen, Germany

Correspondence to Larissa Valor-Méndez;larissa. valormendez@uk-erlangen.de
Dear Editor,

A 58-year-old woman presented with massive nodulous lesions on her hands and feet in our outpatient clinic in spring 2018. She had a history of seropositive erosive rheumatoid arthritis (RA) starting in 2005 with first nodules appearing in 2008. The patient had received sequential treatments with prednisolone, methotrexate $15 \mathrm{mg}$ /week for 4 years and stopped in 2012, leflunomide for 3 years and adalimumab until presentation. Over the years, hand and feet nodules worsened impairing her function. She also developed skin lesions around the nodules leading to severe recurrent local infections requiring surgical removal of some of the nodules, ultimately necessitating the amputation of two digits. At presentation, the patient showed massive nodular deformations and palpable subcutaneous soft nodules, some of which emptied spontaneously (figure 1A). MRI showed pronounced and widespread soft tissue deposits in her right hand with virtually complete disappearance of the physiological joint surfaces in the absence of active synovialitis and a carpal collapse with complete destruction of the os lunatum, partial destruction of the os scaphoideum and os triquetrum (figure 1C). A dual-energy-CT did not show any deposition of uric acid crystals.

Incisional biopsy specimens of the affected tissue showed extensive confluent amorphous necrosis surrounded by palisade-like histiocytes, epitheloid and Langhans cells, as well as fibrosclerotic connective tissue with dense lymphoplasma infiltrates, resembling a rheumatoid nodule. Ziehl Neelsen stain, $M$. tuberculosis culture and PCR were negative. In combination with antibiotic treatment to control local infection, which was

\section{Key messages}

What is already know about this study?

- Rheumatoid nodules are associated with seropositive RA and found in a subset of RA patients, usually in those with severe disease.

What does the study add?

- This is the first study showing the JAK inhibitor baricitinib as effective therapeutic option in a severe RA nodulosis.

How might this impact on clinical practice or future developments?

- JAK inhibitors might be a therapeutic option in this clinical setting.

resolved within 10 days, we started treatment with the JAK Inhibitor baricitinib (4 mg/day). At 2-year follow-up, nodules substantially regressed upon treatment with baricitinib and no further infection occurred (figure 1B).

Rheumatoid nodules are associated with seropositive RA and found in a subset of RA patients, usually in those with severe disease. Some treatments for RA, such as methotrexate, leflunomide, tumour necrosis factor and interleukin-6 receptor inhibitors can paradoxically enhance nodule growth. ${ }^{1-5}$ While rheumatoid nodule formation is usually mild, it occasionally can be severe. In this patient, nodule formation was excessive, highly destructive and life threatening due to the associated soft tissue infections.

Contributors LVM, MH, AK, BM and GS contributed to the treatment design and patient management; LVM conceived the presented idea and wrote the paper with input from GS.

Funding The authors have not declared a specific grant for this research from any funding agency in the public, commercial or notfor-profit sectors.

Competing interests None declared.

Patient consent for publication Consent obtained directly from patient(s). 


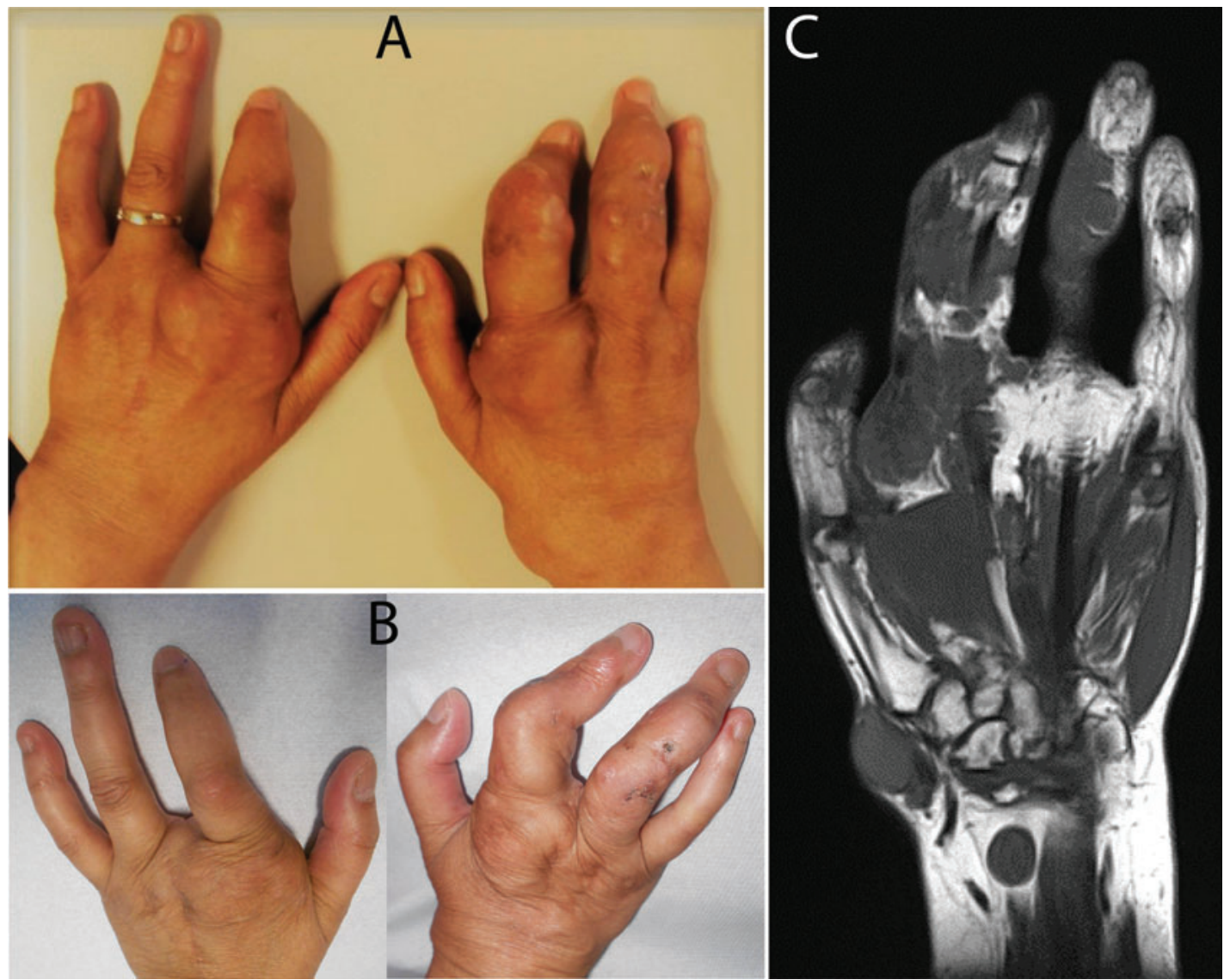

Figure 1 Massive nodular deformations and palpable subcutaneous soft nodules (A). At 2-year follow-up, nodules substantially regressed upon treatment with baricitinib (C). MRI right hand with pronounced and widespread soft tissue deposits (B).

Ethics approval Consent obtained directly from the patient.

Provenance and peer review Not commissioned; externally peer-reviewed. Data availability statement Not applicable.

Open access This is an open access article distributed in accordance with the Creative Commons Attribution Non Commercial (CC BY-NC 4.0) license, which permits others to distribute, remix, adapt, build upon this work noncommercially, and license their derivative works on different terms, provided the original work is properly cited, appropriate credit is given, any changes made indicated, and the use is non-commercial. See: http://creativecommons. org/licenses/by-nc/4.0/.

\section{ORCID iDs}

Larissa Valor-Méndez http://orcid.org/0000-0001-8740-9615 Bernhard Manger http://orcid.org/0000-0003-2375-0069

\section{REFERENCES}

1 Patatanian E, Thompson DF. A review of methotrexateinduced accelerated nodulosis. Pharmacotherapy 2002;22:1157-62.

2 Braun MG, Van Rhee R, Becker-Capeller D. Development and/or increase of rheumatoid nodules in RA patients following leflunomide therapy. Z Rheumatol 2004;63:84-7.

3 Kekow J, Welte T, Kellner U, et al. Development of rheumatoid nodules during anti-tumor necrosis factor alpha therapy with etanercept. Arthritis Rheum 2002;46:843-4.

4 Mackley CL, Ostrov BE, loffreda MD. Accelerated cutaneous nodulosis during infliximab therapy in a patient with rheumatoid arthritis. $J$ Clin Rheumatol 2004;10:336-8.

5 Talotta R, Atzeni F, Batticciotto A, et al. Accelerated subcutaneous nodulosis in patients with rheumatoid arthritis treated with tocilizumab: a case series. J Med Case Rep 2018;12:154. 